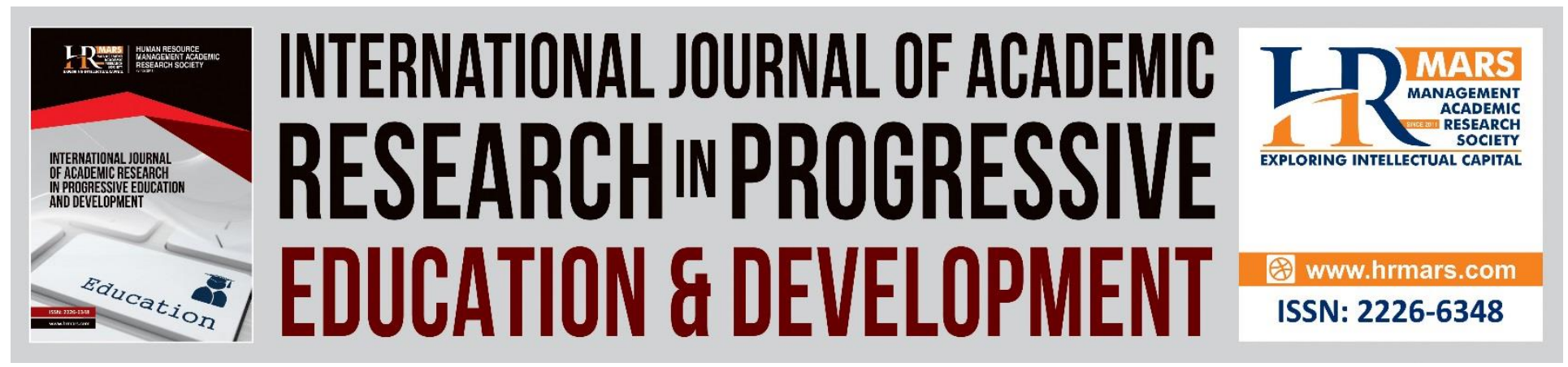

\title{
Collaborative Support of Typical Students in Developing an Inclusive Environment in Mainstream Classes
}

\author{
Manisah Mohd. Ali, Muhamad Al Amran Hamzah
}

To Link this Article: http://dx.doi.org/10.6007/IJARPED/v8-i4/6775

DOI:10.6007/IJARPED/v8-i4/6775

Received: 17 November 2019, Revised: 30 November 2019, Accepted: 16 December 2019

Published Online: 30 December 2019

In-Text Citation: (Ali \& Hamzah, 2019)

To Cite this Article: Ali, M. M., \& Hamzah, M. A. A. (2019). Collaborative Support of Typical Students in Developing an Inclusive Environment in Mainstream Classes. International Journal of Academic Research in Progressive Education and Development, 8(4), 846-857.

Copyright: (C) 2019 The Author(s)

Published by Human Resource Management Academic Research Society (www.hrmars.com)

This article is published under the Creative Commons Attribution (CC BY 4.0) license. Anyone may reproduce, distribute, translate and create derivative works of this article (for both commercial and non-commercial purposes), subject to full attribution to the original publication and authors. The full terms of this license may be seen

at: $\underline{\text { http://creativecommons.org/licences/by/4.0/legalcode }}$

\section{Vol. 8(4) 2019, Pg. 846 - 857}

Full Terms \& Conditions of access and use can be found at http://hrmars.com/index.php/pages/detail/publication-ethics 


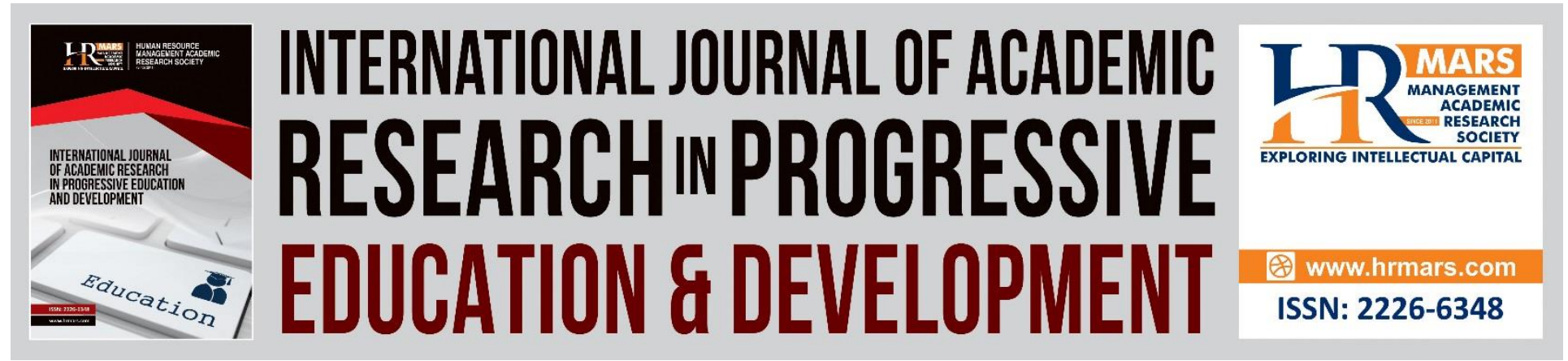

\title{
Collaborative Support of Typical Students in Developing an Inclusive Environment in Mainstream Classes
}

\author{
Manisah Mohd. Ali \\ Faculty of Education, Universiti Kebangsaan Malaysia \\ Malaysia \\ Email: mma@ukm.edu.my \\ Muhamad Al Amran Hamzah \\ Sekolah Kebangsaan Merchong Jaya, Kg.Kajang, Pekan, \\ Pahang, Malaysia
}

\begin{abstract}
This study aims at identifying typical student support aspects in the developing of inclusive environment in schools. The objective of this research is to identify factors influencing the acceptance by typical students of students with special needs, towards developing an inclusive environment by means of two main themes, namely knowledge and collaborative attitude. The research respondents consisted of 50 typical students $(n=50)$ from primary school Level 2 students in Serian district, Sarawak, with respondents being Year 4, Year 5 and Year 6 students who were selected at random. Data collection method in this survey study was done by questionnaire. Data analysis was performed by descriptive statistics, depicting percentage and frequency. Findings reveal that positive attitude influence is present in an inclusive environment, however it is found that there is lack of knowledge regarding special education students. Additionally, the increase of readiness level in the acceptance of students with special needs has been found to be bolstered through cooperative activities. Discussion highlights that typical students' collaborative support affects development of inclusive environment and influences special education students, particularly in reducing social barriers.

Keywords: Typical Students, Collaborative Support, Students with Special Needs, Inclusive Environment

\section{Introduction}

Exposure to inclusive environment is a beginning process in the formation of a typical student's perception towards special education students. The era of inclusive education development in
\end{abstract}


Malaysia shows that the process of inclusive environment development in schools has been taking place since 1962, through the twinning program of visually impaired children from primary and secondary mainstream schools (Kementerian Pendidikan Malaysian, 2016). By means of implementing values of togetherness, acceptance and cooperation, a support system that strongly impacted the formation of inclusive environment in schools was fostered. Indirectly, it led to a better understanding of those who are with special needs. This, in turn, was based on collaborative and social processes involving cooperation among many parties, with the emphasis being on individuals with special needs (Carlson \& Kittay, 2010). Although this development of inclusive environment demonstrated an upward trend, the issue of negative stereotyping still persisted among typical students (Brostrand, 2006; White, Jackson \& Gordon 2006; Longoria 2006). This problem can be noted by scrutinizing the neglect, discrimination and segregation of students with special needs in inclusive environments, so much so that it hindered their assimilation process. This resulted in the implementation of an inclusive environment not being able to be executed because of inadequate support from typical students.

Issues related to inclusive education are global in nature. In line with advances in inclusive education development, it is appropriate that this matter be studied in-depth, especially in relation to typical students. Panagiotou et al. (2008) suggest that creating inclusive environment in schools requires a fresh approach that encompasses planning, cooperation and awareness-creation programs among typical individuals. This would entail activities that foster collaboration between typical students and students with special needs such as sports activities. Most studies tend to look at the aspect of teacherstudent with special needs, but the impact of typical students has largely been not researched. Thus this needs to be addressed in light of current developments.

\section{Inclusive Environment and Collaborative Environment}

The era of inclusive environment development in Malaysia began since 1962 in Malaysia through the twinning program of visually impaired children from primary and secondary mainstream schools (Integrated Special Education Program, Malaysian Education Ministry 2016). However, the problem of social barriers still continued to of challenge to students with special needs. The introduction of inclusive education in schools brought about a positive transformation in the landscape of school. There are a number of factors that made this inclusivity effective; these include typical students themselves becoming contributors towards the success of inclusivity efforts. However, the dilemma of typical students who reject inclusive environment by placing obstacles between themselves and students with special needs is seen as one contributing reason why children with special needs find it difficult to secure places in schools. Indirectly, students with special needs are also perceived as a form of hindrance to the progress of their school. This has been proven by the studies of Siperstein, Parker and Bardon (2007) in which typical individuals were seen to be less cooperative in inclusive classes that were attended by children with special needs. This was a result of lack of awareness among typical students with regards to students with special needs, so much so that this demands a new approach and specialized planning which subsequently can be practically executed (Eleweke \& Rodda 2002; Panagiotou et al. 2008; Salim \& Mansor, 2018; Pătulea \& Marin-Pantelescu, 2018) through 
attitude-changing agents in relation to socializing and perception involving students with special needs (Ajodhia-Andrews \& Elaine Franke 2010).

Collaborative support to develop inclusive environment in schools requires sufficient knowledge among typical students regarding students with special needs so that the necessary relationships are manifested through healthy social interaction. This fosters togetherness between these two groups and negative attitudes can then be minimized. Knowledge on individuals with special needs has the potential to contribute to attitude changes and positive perception of them (Loo. 2004; Ali \& Salleh 2017). A large segment of students with special needs experience slower growth physically, emotionally and intellectually. More worryingly, many of these students find it difficult to understand their academic lessons, let alone excel in them (Siperstein et al. 2007). Despite this, the issues can be minimised with demonstrations of emotional and social support from the environment they live in (Ruijs et al. 2010). The students can be encouraged to become more positive by means of promoting socialization among themselves and this can be evidenced when they have friends from among the children with special needs (Abd Majid et. Al 2017; Salleh \& Ali 2007). Sports too can be utilized as a strong positive influence on typical students. This is especially so when typical students are involved in physical activities in an inclusive manner (Panagiotou et al. 2008). The typical student who is exposed to a positive atmosphere within the inclusive environment needs to not only be accommodative but also have a sense of realization, especially within the learning realm. Therefore, the necessary support for collaborative activity needs to be provided to assess the extent to which typical students can then, in turn, render their support towards the creation of an inclusive environment in their school. The objective of this research is to identify the relationship between typical students' knowledge and the collaborative activity that involves students with special needs, in creating an inclusive environment. The context of this research is in reference to aspects of knowledge and collaborative support. This study was conducted at one of the schools in the district of Serian in order to study typical students' knowledge level with regards to inclusive environment in schools. This study analyzes in detail the following questions:

1. What is the students' knowledge level of inclusive environment?

2. What is the collaborative attitude level of typical students towards students with special needs in an inclusive environment?

\section{Research Methodology}

This research, in the form of a survey study, utilized questionnaire as the method for data collection. The set of questionnaire employed in this study encompassed 27-item questions in four parts; Section A comprised demographics; Section B comprised typical students' views of students with special needs in inclusive environment of mainstream classes; Section C consisted of typical students' attitude towards students with special needs in inclusive classes; Section D dealt with collaboration between typical students and students with special needs. A 5-point Likert scale, Strongly Disagree (SD), Disagree (D), Not Sure (NS), Agree (A), and Strongly Agree (SA), was used to provide respondents' response to the items in the questionnaire. 
Vol. 8, No. 4, 2019, E-ISSN: 2226-6348 @ 2019 HRMARS

A total of 50 typical students $(n=50)$ representing the student population at Level 2, from each class in Year 4, Year 5 and Year 6 were randomly selected as respondents for this study. These students were those who had students with special needs placed in their mainstream classes. Data was analyzed using descriptive statistics involving percentages and frequency. The findings were tabulated and presented in the findings section.

\section{Research Findings}

This section presents the findings from the questionnaire administered on the typical students in the district of Serian, Sarawak. The data are distributed according to two aspects: knowledge and exposure of typical students to inclusive environment and collaborative attitude of typical students towards students with special needs in inclusive environment.

\section{Knowledge and Exposure of Typical Students to Inclusive Environment}

Findings from gathered questionnaires regarding the aspect of knowledge showed that $30 \%$ of respondents in the study had low knowledge concerning similarities of students with special needs with themselves in terms of physical and mental aspects; Three (6\%) respondents stated they strongly disagreed that students with special needs were the same as them physically and intellectually, and $14 \%(n=7)$ disagreed that students with special needs were the same as them physically and intellectually. The majority of respondents $(72 \%, n=36)$ said they were not sure that students with special needs were the same as them physically and intellectually. In contrast, $8 \%$ of respondents thought that students with special needs were the same as them physically and intellectually while $2 \%(n=1)$ strongly agreed that students with special needs were the same as them physically and intellectually.

Meanwhile, $8 \%$ of respondents had never interacted with students with special needs through co-curriculum activities; $4 \%(n=2)$ said they strongly disagreed to having interacted with students with special needs through co-curriculum activities, with another $4 \%(n=2)$ saying they did not agree to having interacted with students with special needs through co-curriculum activities. Even so, the majority of $66 \%$ respondents stated that they had interacted with students with special needs through co-curriculum activities, that is, $22 \%(n=11)$ respondents agreed and another $44 \%(n=22)$ respondents strongly agreed to having interacted with students with special needs through co-curriculum activities.

Additionally, $6 \%$ of respondents did not have friends who were students with special needs, with $2 \%$ strongly disagreeing having at least one friend who was a student with special needs and $4 \%(n=2)$ of respondents did not agree to having at least one friend who was a students with special needs. Also $18 \%(n=9)$ of respondents were not sure if they had at least one friend who was a special education student. However, $76 \%$ of respondents had friends who were students with special needs, with $26 \%(n=13)$ of respondents agreeing having at least one friend who was a student with special needs, and $50 \%(n=25)$ other respondents strongly agreeing to having at least one friend who was a student with special needs.

Next, $12 \%$ of respondents had low knowledge regarding rights of students with special needs studying with typical students, that is, $2 \%(n=1)$ of respondents strongly disagreed that students with special needs had rights of studying with typical students and $10 \%(n=5)$ of respondents disagreed that students with special needs had rights of studying with typical 
students. Furthermore, $44 \%$ of respondents were not sure if students with special needs had rights of studying with typical students. However, another $44 \%$ of respondents were of the opinion that students with special needs had rights of studying with typical students, with $26 \%$ $(n=13)$ of respondents agreeing students with special needs had rights of studying with typical students, and $18 \%(n=9)$ of respondents strongly agreeing that students with special needs had rights of studying with typical students.

It was also found that $30 \%$ of respondents were not prepared to contribute ideas to students with special needs while learning in inclusive classes, with $8 \%(n=4)$ respondents declaring they were very disagreeable with the idea of contributing ideas to students with special needs when learning in inclusive classes, while $22 \%(n=11)$ did not agree to contribute ideas to students with special needs while learning in inclusive classes. Still, the majority of respondents were prepared to contribute ideas to students with special needs while learning in inclusive classes, with $28 \%(n=14$ ) asserting that they were very agreeable while $42 \%$ stated that they agreed.

Next, $50 \%$ ( $n=25$ ) of respondents displayed doubts in terms of their skills to assist students with special needs of inclusive classes inside, and outside of the classroom. The other $50 \%$, however, felt that they had the skills to help these students in teaching and learning activities both inside and outside the classroom, with $4 \%(n=2)$ of respondents being very agreeable, and $46 \%(n=23)$ of respondents agreeing to help these students in teaching and learning activities both inside and outside the classroom. Table 1 below summarizes the feedback of respondents concerning knowledge and exposure in an inclusive environment with regards to students with special needs. 
Vol. 8, No. 4, 2019, E-ISSN: 2226-6348 @ 2019 HRMARS

Table 1: Knowledge and Exposure of Typical Students towards Inclusive Environment

\begin{tabular}{|c|c|c|c|c|c|c|c|c|}
\hline \multirow[t]{2}{*}{ No. } & \multirow[t]{2}{*}{ Item } & \multicolumn{7}{|c|}{ Result (Frequency/ Percentage / Mean / SD) } \\
\hline & & SD & $D$ & NS & A & SA & MEAN & SD \\
\hline i. & $\begin{array}{l}\text { I feel students with } \\
\text { special needs are the } \\
\text { same as me physically } \\
\text { and intellectually.? }\end{array}$ & $\begin{array}{c}3 \\
(6 \%)\end{array}$ & $\begin{array}{c}7 \\
(14 \%)\end{array}$ & $\begin{array}{c}36 \\
(72 \%)\end{array}$ & $\begin{array}{c}3 \\
(6 \%)\end{array}$ & $\begin{array}{c}1 \\
(2 \%)\end{array}$ & 2.84 & 0.71 \\
\hline ii. & $\begin{array}{l}\text { I have interacted with } \\
\text { students with special } \\
\text { needs through co- } \\
\text { curriculum activities. }\end{array}$ & $\begin{array}{c}2 \\
(4 \%)\end{array}$ & $\begin{array}{c}2 \\
(4 \%)\end{array}$ & $\begin{array}{c}13 \\
(26 \%)\end{array}$ & $\begin{array}{c}11 \\
(22 \%)\end{array}$ & $\begin{array}{c}22 \\
(44 \%)\end{array}$ & 3.98 & 1.116 \\
\hline iii. & $\begin{array}{l}\text { I have at least one } \\
\text { friend from among } \\
\text { students with special } \\
\text { needs. }\end{array}$ & $\begin{array}{c}1 \\
(2 \%)\end{array}$ & $\begin{array}{c}2 \\
(4 \%)\end{array}$ & $\begin{array}{c}9 \\
(18 \%)\end{array}$ & $\begin{array}{c}13 \\
(26 \%)\end{array}$ & $\begin{array}{c}25 \\
(50 \%)\end{array}$ & 4.18 & 1.004 \\
\hline iv & $\begin{array}{l}\text { Students with special } \\
\text { needs have rights to } \\
\text { study together with } \\
\text { typical students. 目 }\end{array}$ & $\begin{array}{c}1 \\
(2 \%)\end{array}$ & $\begin{array}{c}5 \\
(10 \%)\end{array}$ & $\begin{array}{c}22 \\
(44 \%)\end{array}$ & $\begin{array}{c}13 \\
(26 \%)\end{array}$ & $\begin{array}{c}9 \\
(18 \%)\end{array}$ & 3.48 & 0.974 \\
\hline $\mathrm{v}$ & $\begin{array}{l}\text { I am ready to } \\
\text { contribute ideas to } \\
\text { students with special } \\
\text { needs in inclusive } \\
\text { classes. }\end{array}$ & $\begin{array}{c}4 \\
(8 \%)\end{array}$ & $\begin{array}{c}11 \\
(22 \%)\end{array}$ & $\begin{array}{c}0 \\
(0 \%)\end{array}$ & $\begin{array}{c}21 \\
(42 \%)\end{array}$ & $\begin{array}{c}14 \\
(28 \%)\end{array}$ & 3.90 & 0.909 \\
\hline vi & $\begin{array}{l}\text { I am skilled in helping } \\
\text { students with special } \\
\text { needs in inclusive } \\
\text { learning and teaching } \\
\text { activities inside and } \\
\text { outside classrooms } \\
\text { didalam dan diluar } \\
\text { kelas. }\end{array}$ & $\begin{array}{c}0 \\
(0 \%)\end{array}$ & $\begin{array}{c}0 \\
(0 \%)\end{array}$ & $\begin{array}{c}25 \\
(50 \%)\end{array}$ & $\begin{array}{c}23 \\
(46 \%)\end{array}$ & $\begin{array}{c}2 \\
(4 \%)\end{array}$ & 3.54 & 0.579 \\
\hline
\end{tabular}

SD= Strongly Disagree, $D=$ Disagree, NS= Not Sure, A=Agree, SA=Strongly Agree 


\section{Collaborative Attitude of Typical Students towards Students with special needs in Inclusive Environment}

In terms of attitude in involvement, the majority - $80 \%$ of respondents in this survey - had high involvement in relation to not feeling shy to befriend students with special needs, with $40 \%$ ( $n=$ 20) saying that they strongly disagreed as to feeling shy about befriending students with special needs, while the other $40 \%(n=20)$ stated they disagreed that they felt shy about being friends with students with special needs. Also, $20 \%(n=10)$ of respondents felt not sure about feeling shy when befriending students with special needs. Interestingly, not even one respondent agreed to feeling shy about being friends with students with special needs.

Meanwhile, $64 \%$ of respondents had no reservations in taking in students with special needs as one of their group members, with $42 \%(n=21)$ asserting that they strongly disagreed having reservations in taking in students with special needs as one of their group members, and $22 \%(n=11)$ of the other respondents replied that they disagreed having reservations taking in students with special needs as one of their group members. On the other hand, $32 \%(n=16)$ of respondents were not sure that the presence of students with special needs would slow down their learning process in class. Only $4 \%(n=2)$ of respondents said that they strongly agreed to having reservations in accepting students with special needs as group members.

The majority, that is $64 \%$ of respondents, had a positive attitude concerning the presence of students with special needs, with $28 \%(n=14)$ of respondents strongly disagreeing to presence of students with special needs slowing down their learning process in class, with $36 \%(n=18)$ of the balance respondents disagreeing that presence of students with special needs slowed down their learning process in class. Additionally, $28 \%(n=14)$ of respondents were not sure of having at least one friend from among special education students, but $8 \%(n=4)$ of respondents agreed the presence of students with special needs slowed down their learnig process in class. Table 2 presents feedback of respondents with regards to attitude towards inclusive environment with students with special needs. 
Vol. 8, No. 4, 2019, E-ISSN: 2226-6348 @ 2019 HRMARS

Table 2: Collaborative Attitude of Typical Students Towards Students with Special Needs in Inclusive Environment

\begin{tabular}{|c|c|c|c|c|c|c|c|c|}
\hline \multirow[t]{2}{*}{ No. } & \multirow[t]{2}{*}{ Item } & \multicolumn{7}{|c|}{ Result (Frequency/ Percentage / Mean / SD) } \\
\hline & & SD & $\mathrm{D}$ & NS & A & SA & MEAN & SD \\
\hline i. & $\begin{array}{l}\text { I feel shy when } \\
\text { befriending } \\
\text { students with } \\
\text { special needs. }\end{array}$ & $\begin{array}{c}20 \\
(40 \%)\end{array}$ & $\begin{array}{c}20 \\
(40 \%)\end{array}$ & $\begin{array}{c}10 \\
(20 \%)\end{array}$ & $\begin{array}{c}0 \\
(0 \%)\end{array}$ & $\begin{array}{c}0 \\
(0 \%)\end{array}$ & 1.80 & 0.756 \\
\hline ii. & $\begin{array}{l}\text { I have reservations } \\
\text { taking in students } \\
\text { with special needs } \\
\text { as my group } \\
\text { member. }\end{array}$ & $\begin{array}{c}21 \\
(42 \%)\end{array}$ & $\begin{array}{c}11 \\
(22 \%)\end{array}$ & $\begin{array}{c}16 \\
(32 \%)\end{array}$ & $\begin{array}{c}0 \\
(0 \%)\end{array}$ & $\begin{array}{c}2 \\
(4 \%)\end{array}$ & 2.02 & 1.059 \\
\hline iii. & $\begin{array}{l}\text { The presence of } \\
\text { students with } \\
\text { special needs slows } \\
\text { down my learning } \\
\text { process in class. }\end{array}$ & $\begin{array}{c}14 \\
(28 \%)\end{array}$ & $\begin{array}{c}18 \\
(36 \%)\end{array}$ & $\begin{array}{c}14 \\
(28 \%)\end{array}$ & $\begin{array}{c}4 \\
(8 \%)\end{array}$ & $\begin{array}{c}0 \\
(0 \%)\end{array}$ & 2.16 & 0.934 \\
\hline
\end{tabular}

$\mathrm{SD}=$ Strongly Disagree, $\mathrm{D}=$ Disagree, NS= Not Sure, $\mathrm{A}=$ Agree, $\mathrm{SA}=$ Strongly Agree

\section{Discussion}

Research findings indicate that typical students who have at least one friend from among students with special needs do not feel shy and are drawn towards positive attitudes when interacting with special education students. This demonstrates that the frequency which a typical student spends with students with special needs makes them more inclined to befriend and interact with this group, as highlighted in earlier studies whereby it was shown that an individual is likely to be more positive compared to those who rarely interact with students with special needs (Perry, Ivy, Conner, \& Shelar, 2008).

In this regard, the attitude of wanting to get to know one another creates a positive environment in collaborative learning activities, both inside and outside classrooms. Indeed, the feeling of shyness will be dispelled if they learn together while enhancing their academic performance at the same time. Thus, the relationship between academics and socio-emotions is seen to provide a natural effect on the academic achievement and social aspect of the typical student (Ruijs et al. 2010). On the same note, teachers contribute to the development of inclusive environment by maximizing students involvement through creative teaching and learning activities and provide equal opportunity for all students to participate in these activities (Ali \& Hassan 2014).

Other than that, collaborative activities in sports is also seen to reduce negative stereotyping and social barriers with regards to students with special needs. Findings of analysis illustrate that the large number of respondents who support sporting activities are the best medium for 
cooperation in games. This research finding supports past studies by affirming that there was greater positive attitude shown among students from Grades 5 and 6 in inclusive environment during physical education sessions after the Paralympic education programs (Panagiotou et al. 2008). Thus it can be surmised that fostering of positive attitudes and collaboration can indeed occur during sports activities.

The relationship between knowledge and collaborative activities shows that there is positive correlation with regards to ties between typical students and students with special needs. Research findings depict that the higher the knowledge of typical students regarding students with special needs, the more they are capable of contributing to greater collaborative activity growth. As emphasized by Hwang and Evans (2011), this can be enhanced by having a proper infra structure and environment would promote better and positive interactions among these students.

Additionally, the findings reveal that high knowledge level among typical students of students with special needs is found to be lacking. The majority of respondents displayed poor knowledge and exposure levels regarding students with special needs. So it is appropriate that school authorities carry out programs that are inclusive in nature by putting students with special needs in the forefront at school. Indirectly, this would serve to heighten awareness of the community and typical students about students with special needs.

Research findings also show positive trends of typical students and students with special needs interacting and making befriending each other in school, particularly in inclusive classes. Promotion of creating a better inclusive environment among teachers and students can be carried out via programs such as mentor-mentee, and also by grouping typical students with students with special needs in schools activities. The more frequently these groups interact and mingle, the more the gap between these groups can be reduced and barriers of students with special needs in inclusive classes minimized. As such, this would provide a better understanding and further promote positive perception towards students with special needs (Alias 2013; Perry, et al. 2008). All students can be educated through accommodative approaches and redesigning tasks which would demonstrate an appreciation of challenges that students with special needs encounter in school as well as outside school.

\section{Conclusion}

It is essential to develop understanding of students with special needs in inclusive environments at school in order to help them participate fully in this inclusive environment. The support received from typical students can also reduce the gap between typical students and students with special needs and subsequently foster positive values, besides creating a spirit of cooperation. It would also diminish the stereotyping trait that is prevalent among typical students. This study notes that the lack of knowledge among typical students regarding students with special needs can block students with special needs from having equitable rights in education and consequently lead to them being discriminated as well. It is hoped that enhancing facilities and professional workforce in the inclusive environment can enhance the outcomes, perception and positive atmosphere in schools. Other than that, it is the responsibility of teachers, administrators and students to adopt the collaborative approach in practicing better 
Vol. 8, No. 4, 2019, E-ISSN: $2226-6348$ @ 2019 HRMARS

social skills and interaction in schools. The social culture can also help fortify continual inclusive education. The support of typical students in the development of inclusive environment in schools needs to be refined in the implementation context, for example through awareness programs and building network of friends among students so that they can be more tolerant and understanding of each other's strengths and weaknesses. This study proposes further research that focuses on exploring factors that influence typical students' knowledge of the disability of special education students, their attitudes, and methods of collaboration in inclusive education using larger and more representative survey samples.

\section{Acknowledgement}

The study was supported by the grant from the Faculty of Education, Universiti Kebangsaan Malaysia, GG-2019-003.

\section{References}

Majid, A. R., Ali, M. M., Salleh, N. M., Alias, A., \& Kanapathy, R. (2017). Dinamik holistik pembangunan potensi individu untuk kecemerlangan dan kesejahteraan. Prosiding Konvensyen Kebangsaan Sekolah Kluster Kecemerlangan 2017.

Ajodhia-Andrews, A., \& Frankel, E. (2010). Inclusive Education in Guyana: A Call for Change. International Journal of Special Education, 25(1), 126-144.

Ali, M. M., \& Hassan, N. (2014). Perspektif Guru terhadap Keterlibatan Akademik dalam Kalangan Murid dengan Ketidakupayaan Penglihatan (Teachers' Perspectives on Academic Engagement of Students with Visual Impairments). Malaysian Journal of Education, 39(2), 109-114.

Ali, M. M., \& Salleh, N. M. (2017). Kecemerlangan dalam pembudayaan persekitaran inklusif mesra pembelajaran. Prosoiing Konvensyen Kebangsaan Sekolah Kluster Kecemerlangan 2017.

Alias, A. (2013). The issues in implementing transition program for special needs students. Asian Social Science, 9(16), 9.

Brostrand, H. L. (2006). Tilting at windmills: Changing attitudes toward people with disabilities. Journal of Rehabilitation, 72(1), 4

Carlson, L., \& Kittay, E. F. (2010). Introduction: Rethinking Philosophical Presumptions in Light of Cognitive Disability. Cognitive Disability and Its Challenge to Moral Philosophy, 1-25.

Eleweke, C. J., \& Rodda, M. (2002). The challenge of enhancing inclusive education in developing countries. International Journal of Inclusive Education, 6(2), 113-126.

Kementerian Pendidikan Malaysia. (2016). Program Pendidikan Khas Integrasi. Retrieved November 5, 2016, from http://www.moe.gov.my/v/program-pendidikan-khas-integrasiinformasi-program.

Longoria, L., \& Marini, I. (2006). Perceptions of children's attitudes towards peers with a severe physical disability. Journal of Rehabilitation, 72(3), 19.

Loo, R. (2004). Relationships between attitudes toward euthanasia and attitudes toward persons with disabilities. The Social Science Journal, 41(2), 295-299.

Hwang, Y. S., \& Evans, D. (2011). Attitudes towards inclusion: Gaps between belief and practice. International Journal of Special Education, 26(1), 136-146. 
Perry, T. L., Ivy, M., Conner, A., \& Shelar, D. (2008). Recreation student attitudes towards persons with disabilities: considerations for future service delivery. Journal of Hospitality, Leisure, Sports and Tourism Education (Pre-2012), 7(2), 4.

Panagiotou, A. K., Evaggelinou, C., Doulkeridou, A., Mouratidou, K., \& Koidou, E. (2008). Attitudes of 5 th and 6 th grade greek students toward the inclusion of children with disabilities in physical education classes after a paralympic education program. European Journal of Adapted Physical Activity, 1(2).

Pătulea, D.M., Marin-Pantelescu, A. (2018). Exploratory Research in the Tertiary Sector: Romanian Preferences for Cultural Services, International Journal of Academic Research in Accounting, Finance and Management Sciences 8 (3): 83-94

Ruijs, N. M., Veen, V. D. I., \& Peetsma, T. T. (2010). Inclusive education and students without special educational needs. Educational Research, 52(4), 351-390.

Salleh, N. M., \& Ali, M. M. (2007). Social Relationships Skills of Students with Special Needs in Inclusive Programs. International Journal of Learning, 14(4).

Siperstein, G. N., Parker, R. C., Bardon, J. N., \& Widaman, K. F. (2007). A national study of youth attitudes toward the inclusion of students with intellectual disabilities. Exceptional children, 73(4), 435-455.

Stough, L. M. (2003). Special education and severe disabilities in Costa Rica: Developing inclusion in a developing country. Research and practice for persons with severe disabilities, $28(1)$, 7-15.

Salim, N. R., \& Mansor, I. (2018). Training and Teaching of Arabic Translation Course in IPG: Perspectives of Trainees and Trainers. International Journal of Academic Research in Progressive Education and Development, 7(4), 364-375.

White, M. J., Jackson, V., \& Gordon, P. (2006). Implicit and explicit attitudes toward athletes with disabilities. Journal of Rehabilitation, 72(3). 